\title{
How Independence Saved an African Reserve
}

\author{
By G. D. Hayes
}

Before 1939 the Lengwe game reserve in Nyasaland sheltered a wide range of large animals, including the rare nyala antelope for whose protection it was originally declared. By the end of the war, with invasions and settlement and large-scale poaching, it hardly qualified as a reserve at all, says the author, who is honorary secretary of the Fauna Preservation Society of Malawi; and the situation was not much better in 1964 when the country achieved independence as Malawi. Then, thanks to the personal interest of Dr. Banda, a decision to abolish the reserve was reversed and a new water supply installed which has transformed the situation.

THE latest developments in the Lengwe Game Reserve of Malawi are a perfect demonstration of nature's ability to protect an animal species if given but half a chance. Since the end of the second world war the story of this reserve has been one of continual struggle for survival, and one that has more than once been all but lost. The credit for its survival despite all attempts to abolish it must, to some extent, go to the Fauna Preservation Society of Malawi (formerly the Nyasaland Fauna Preservation Society) with invaluable assistance from the Fauna Preservation Society in London.

The Lengwe reserve is in the Chikwawa district of southern Malawi, one of two known as the Lower River districts, and covers some fifty square miles of mixed park-like country, with large, very dense thickets in which the rare nyala antelope Tragelaphus angasii finds sanctuary. It was first declared a game reserve in 1928, on the advice of the late Rodney Wood, in order to preserve the nyala, which are to be found in isolated patches of dense jungle throughout south-east Africa but nowhere north of the Chikwawa district of Malawi. Before the second world war the reserve contained, in addition to an unknown number of nyala antelope, many other species including elephant, buffalo, eland, kudu, hartebeest and bushbuck; zebra and impala were to be found in the more open areas to the south. But during the war, with lack of government supervision, there was a considerable influx of people, sometimes whole villages, from Portuguese territory, leading to general lawlessness and poaching. By 1945 the numbers of wild animals to be found anywhere in Chikwawa had been reduced considerably and the Lengwe reserve hardly qualified as a reserve at all.

Shortly after the war, the Nyasaland Government established a department of Game, Fish and Tsetse Control, but the emphasis was more on 'control' than preservation, and animal numbers everywhere continued to decrease. Puku Adenota vardonii, which could at one time be found in hundreds along the Bua and Rusa rivers in the 
Kasungu district, disappeared completely; one now has to go to the Luangwa valley of Zambia to find this antelope. All attempts at preservation were invariably met by the argument that the alienation of land would meet violent opposition from the agricultural community and could not, therefore, be considered. This may well have been true, but no serious attempt was ever made to 'test the wind' and the few half-hearted efforts to establish game reserves as tourist attractions were frustrated, if not by lack of intention, then by lack of funds. If the feeling among wildlife conservationists, both official and unofficial, was one of complete frustration at this time it is hardly surprising; by 1964 the position had become desperate.

With the advent of independence the preconceived notions regarding the African attitude towards wildlife conservation proved to be completely erroneous and, under the enlightened leadership of Dr. Banda, matters took a distinct turn for the better-though not immediately for the Lengwe Reserve. The establishment of a sugar development project close to the reserve, and between it and the Shire and Mwanza rivers, seemed certain to sound its death knell, and in fact a decision was taken to abolish the reserve and to capture and remove the few (as was then thought) remaining nyala to the Mwabvi reserve in the Port Herald district some fifty miles away.

\section{More Nyala Discovered}

Luckily, responsibility for game matters had been taken over, early in 1963, by the Forestry Department, renamed the Department of Forestry and Game; this added a number of keen wildlife conservationists to the staff. Investigations by the new department established that there were far more nyala hiding in the Lengwe thickets than had at first been thought possible. This discovery, added to expert advice against attempting to capture animals in Lengwe conditions, decided the Government to reverse the decision to abolish the reserve. The Director of Forestry and Game then pointed out that something must be done immediately about water supplies within the reserve. Previously the animals had gone to either the Mwanza or Shire rivers, but the new cultivation between the reserve and these rivers made such forays hazardous in the extreme, and all known water-holes inside the reserve would be dry by the end of August. On the direct orders of Dr. Banda a bore-hole was sunk within some three hundred yards of the Magomero water-hole, the largest so far known to exist, and water was then piped from the bore to the water-hole.

This changed the outlook completely, and a number of species long thought to have left the reserve appeared at the water during the $\mathbf{1 9 6 4}$ 'hot' season. Nyala, kudu, bushbuck, reedbuck, and Livingstone's suni were all seen that summer, and a herd of some fifty buffalo, which formerly had been only sporadic visitors, stayed in the reserve and so avoided the annual reduction in numbers which had attended previous excursions in search of water; they were, however, very shy and were never seen in the open.

So satisfactory had been the 1964 experience that the Government 
decided to go ahead with development work, and in 1965 a start was made on the erection of a tourist rest camp about half a mile from the water-hole. The FPS of Malawi donated the money to buy a windmill pump to supply water direct to both the water-hole and the camp. The camp was not officially open to the public in 1965 , but word had got round and a number of people spent highly successful days viewing animals from a temporary 'hide' which the game ranger in charge of the reserve, Mr. L. Kettle, had built for their convenience. In addition to the species seen in 1964, the 1965 'bag' included a troop of the rare nchima or blue Samango monkeys Cercopithicus mitis, and numbers of mongooses, as many as twenty-four being seen together. Baboons, vervet monkeys, warthogs and bush-pigs were frequently seen, while lion, leopard, hyena and some of the smaller cats are known to have visited the water. On August 1st, 1966, the rest of the camp was opened. The reserve is efficiently policed by a number of keen guards in the charge of an African game scout, and a system of irregular anti-poaching patrols has kept poaching under control.

At the time of writing, only one month from the opening date, the increase in the numbers of animals seen, both at the water-hole and from cars travelling along the eleven miles of road within the reserve, is quite extraordinary. Three hartebeest have been seen for the first time, and the guards report fresh spoor of eland and zebra, although the presence of these animals has yet to be confirmed. It is the nyala, however, which have made the most startling come-back, and, as the whole existence of the reserve depends on their maintenance in reasonable numbers, this aspect is the most satisfactory.

The nyala is one of the most handsome of the antelopes, and a mixed herd of males, females and young at water in a forest setting is a sight worth seeing. The male, standing about 42 inches at the shoulder and weighing anything up to $300 \mathrm{lb}$., has a fine pair of lyrate horns with ivory white tips. The general colour is dark grey with a number of rather faint vertical white stripes, a white chevron between the eyes, white spots on the face and thighs, and a dark chestnut patch on the forehead; the legs below the knees are also chestnut coloured. The neck is covered with long dark hair which extends all along the belly, and there is a dorsal crest of black and white extending from shoulder to rump.

Nyala Become Less Shy

The females are quite different. A good deal smaller than the males and without horns, their colour is almost orange, with 11-13 narrow, prominent, vertical white stripes, and with white spots on the face and haunches. There is no chevron on the face but a dark line extends from the top of the head to the root of the tail. Both males and females are adorned with large bushy tails, dark above and white beneath. The young males are very similar to the females in colour and general appearance and the first indication of their sex is the 